\title{
APROXIMACIÓN A LA VIDA Y OBRA DEL PINTOR Y ESTOFADOR ALCALAÍNO-GRANADINO PEDRO RAXIS
}

\author{
POR \\ LÁZARO GILA MEDINA \\ Universidad de Granada
}

\begin{abstract}
En el presente trabajo realizamos una aproximación a la vida y la obra de un artista clave para la Granada de la Contrarreforma: Pedro de Raxis, sobrino carnal del escultor Pablo de Rojas -maestro a su vez del también alcalaíno Juan Martínez Montañés-, todos ellos figuras pioneras al enmarcar el paso del renacimiento romanista al primer naturalismo barroco. Creador, igualmente, de un activísimo taller, precursor en la formación de renombrados artistas, fue considerado en su época como el "padre de la estofa", aunque se infravoloró su faceta de pintor.
\end{abstract}

Palabras clave: Pintura y escultura españolas de los siglos XVI y xVII. Granada. Pedro de Raxis

This article offers an approximation to the life and work of Pedro de Raxis, a key artist in Counter Reformation Granada. Raxis was the nephew of the sculptor Pablo de Rojas, who was also the master of Juan Martínez Montañés. All three were from Alcalá de Henares and pioneers in the stylistic transition from the Roman Renaissance to early Baroque naturalism. Raxis also established an extremely active studio, precursor in the formation of famous artists, and during his lifetime was considered to be the "father" of the estofa technique (the sizing, gilding and painting of wooden statuary), although his facet as a painter was underestimated.

Key words: Spanish painting and sculpture, 16 and 17th century. Granada. Pedro de Raxis

\section{INTRODUCCIÓN}

El 18 de mayo de 1626, estando enfermo en sus casas de la Parroquia de las Angustias, otorgaba testamento ${ }^{1}$, ante el escribano Juan de Almazán, el maestro de pintor y estofador Pedro Raxis. A los pocos días, el 6 de junio, recibía sepultura en esa misma iglesia, «con moderada pompa y vestido con el hábito de franciscano», como él mismo había ordenado. Con su óbito, desaparecía uno de los artistas más completos y polifacéticos de la Granada contrarreformista así como un creador de uno de los talleres más prolíficos que jamás se haya conocido esta ciudad.

\footnotetext{
' No se conservan en el Archivo Notarial de Granada (A.N.Gr.) los protocolos de Juan de Almazán. No obstante, una copia de su testamento se encuentra en el Archivo de la Real Chancillería — signatura 402.3393 —, dentro de un grueso volumen relativo a un pleito que algunos miembros de la familia Raxis, sostuvieron con las monjas del convento alcalaíno de la Trinidad por el patronato de un vínculo fundado por Miguel Raxis — un tío carnal de nuestro artista — en 1598, en dicho lugar. Fue la profesora Dr. $\mathrm{D}^{\mathrm{a}}$. Ana María Gómez Román quien nos dio a conocer la existencia de esta copia del testamento aprovechando esta ocasión para mostrarle nuestra gratitud.
} 
Con setenta y un años cumplidos en febrero, su existencia había sido, en líneas generales generosamente fecunda y densa, en todos los sentidos. De ahí que, aunque no sea muy normal en nuestro país, haya sido objeto de merecidos elogios. Loas, que van desde sus mismos contemporáneos; así, por ejemplo, Pacheco en su Arte de la Pintura, resaltaba sus dotes como estofador ${ }^{2}$ hasta el académico Ceán Bermúdez, quien, en los umbrales del siglo xix, afirmaba: se sospecha que haya estudiado en Italia por la buena manera que tenía de pintar, por la exactitud de su dibuxo y por el delicado gusto en los grutesco ${ }^{3}$, pasando por las alabanzas poéticas de otros coetáneos o los panegíricos que diversos cronistas de órdenes religiosas hicieron a algún trabajo para su convento — básicamente pinturas para sus claustros o templos conventuales-.

Mas, en todo caso, son comentarios muy puntuales, por eso, salvo algún que otro apunte biográfico ${ }^{4}$, hasta hace pocos años se desconocía, en gran medida, la trayectoria de este singular maestro de la pintura, de la estofa y del policromado en general de imágenes y retablos. Creador no sólo de un activo taller, que se hace presente en todos los campos de las artes plásticas en muchos lugares de Andalucía, sino también, y a la par, un importante eslabón, junto con su tío, el genial escultor Pablo de Rojas, de esa dilatada familia de artistas, que tuvo su origen en el sardo Pedro Raxis ${ }^{5}$, el Viejo — su abuelo paterno — quien, desde su Cagliari natal — hacia 1528 - , vino a establecerse a Alcalá la Real, sede de una importante Abadía de Patronato Real que, a todos los efectos, funcionó como un pequeño, pero rico y apetecible, obispado.

Tras él, el buen hacer de esta familia, a través de sucesivas generaciones, llegará hasta el siglo XVIII, fundamentalmente en Granada — con la descendencia de nuestro artista-; en Sevilla — con los herederos de su hermano Gaspar - y en Nueva España, primero en México y después en Querétaro - tal vez con los vástagos de su hermano Melchor-.

Así pues, intentamos ofrecer aquí, a través de una serie de etapas, la trayectoria vital y profesional de esta gran personalidad, activa en Granada entre 1575 y 1626 . Periodo que coincide además con ese momento artísticamente tan sutil y delicado que asiste al paso del Manierismo, de clara ascendencia italiana, al naturalismo, de filiación española, de todo lo cual él fue un claro exponente.

\section{LAS ETAPAS DE SU VIDA}

\subsection{Alcalá la Real (1555-1575). Infancia y adolescencia}

Pedro nació en esta ciudad, en 1555, siendo bautizado el 16 de febrero, en la Parroquia de Santo Domingo de Silos ${ }^{6}$. Hijo de Francisca Serrano y de Melchor Raxis (el segundo-génito

\footnotetext{
${ }^{2}$ Edición de Bonaventura Bassegoda i Hugas. Madrid: Cátedra, 1990, p.261.

${ }_{3}^{3}$ Diccionario Histórico de los más ilustres profesores de las Bellas Artes en España. Madrid: Viuda de Ibarra, 1800. Ed. Manuel Morán Turina. Madrid: Akal, 2001, t. IV, pp. 161-162.

${ }^{4}$ La primera aportación de interés nos la ofreció Orozco Díaz, Emilio. Amor, poesía y pintura en Carrillo de Sotomayor. Granada: Universidad, 1967, cap. IV, pp. 121-146. Posteriormente Gómez-Moreno Calera, José Manuel. La arquitectura religiosa granadina en la crisis del Renacimiento (1560-1650), aportó gran cantidad de datos sobre los Raxis granadinos. Por último, me he ocupado personalmente en varias ocasiones de esta familia de artistas: la primera, en el artículo titulado «Los Raxis: importante familia de artistas del Renacimiento Andaluz. A ella perteneció el gran escultor Pablo de Rojas». Archivo Español de Arte (Madrid), 238 (1987), pp. 167-177. Después más ampliamente en mi libro Arte y artistas del Renacimiento en torno a la Real Abadía de Alcalá la Real. Granada: Universidad-Ayuntamiento de Alcalá la Real, 1991, pp. 254-257. Y finalmente, centrándome en la figura de Pedro Raxis y de su tío, Pablo de Rojas, en el artículo: «En torno a los Raxis-Sardo: Pedro de Raxis y Pablo de Rojas en la segunda mitad del siglo xvi». Atrio (Sevilla), 4 (1992), pp. 35-49.

${ }^{5}$ Sobre el fundador de la dinastía y su hijo, Pablo de Rojas, véase mi artículo citado «Los Raxis singular...».

${ }^{6}$ Parroquia Santo Domingo de Silos (A.P.S.D.). Libro de Bautismos. Libro 3, fol. 16.
} 
de Pedro Raxis Sardo, el Viejo, y de Catalina González), desde la misma infancia entraría en contacto con el mundo de la pintura, de la imaginería y de la retablistica a través del taller familiar donde, bajo la dirección de su abuelo, trabajaban, además de su padre, sus otros tíos; a saber: Pedro, Nicolás, Miguel y Pablo —el futuro Pablo de Rojas, tan sólo seis años mayor que él y el único que castellanizó el apellido italiano Raxis por Rojas-.

Allí conocería a los Martínez Montañés — padre e hijo-; al entallador Jusepe de Burgos; a los pintores Rodrigo de Figueroa y a Francisco Hernández — casado con una hermana de su abuela paterna-, entre otros; quienes acudirían a tan prolífico taller no sólo para conocer «in situ» los encargos artísticos que en él se realizaban, sino también para ilustrarse, repasando una y otra vez, esa gran cantidad de libros y material gráfico que sobre estas mismas materias habían traído de Italia su tio Miguel —el noveno hijo de Pedro Raxis, el Viejo, y de Catalina González - cuando, en 1567, acompañando a éste último, viajaron a Cagliari, en Cerdeña, a recoger la herencia paterna, invirtiendo parte de lo recibido en libros de arte. Ahora, precisamente, encuentran plena justificación las palabras antes citadas de Ceán Bermúdez con relación a la influencia italiana de nuestro artista.

Sus padres vivían en la alcalaína calle Real, junto a las casas de los abuelos paternos y además de Pedro, que como su padre fue también el segundo-génito de la familia, tuvieron en total diez hijos: cinco mujeres y otros tantos varones. De éstos, junto a Pedro, siguieron la tradición familiar del cultivo de las artes, los citados Gaspar y Melchor.

Por lo que respecta a su formación, aunque el taller familiar era polifacético en su producción: imágenes, pinturas, retablos, túmulos funerarios, iluminación de libros - miniaturas-, etc.; parece casi una constante en esta familia el que la completaran con algún reconocido maestro del entorno geográfico. Así, por ejemplo, su tío, del mismo nombre y apellido, estuvo algunos años de aprendiz en Jaén con el pintor Antonio Sánchez Ceria. Lo mismo hizo su padre con sus otros dos hermanos - en 1580, autoriza a nuestro artista, ya vecino de Granada, para que en esta ciudad pusiera a su hermano Gaspar de aprendiz de "ensanblador y dibuxador» ${ }^{7}$ con quien le pareciere más oportuno. Y tres años después el padre confiaba Melchor al escultor Sebastián de Solís, vecino de Jaén ${ }^{8}$ -

Si el padre que, en esencia, era escultor —aunque también practicó la pintura-, puso especial empeño en que Gaspar y Melchor completaran su aprendizaje con otro renombrado maestro, lógicamente hemos de pensar que igual interés tendría con Pedro. La solución a este interrogante está en la figura de Juan de Orihuela, su futuro suegro. Un pintor, policromador de retablos y guadamecilero granadino, avecindado en la parroquia de Santa Ana, aún bastante desconocido, pero que desarrolló, junto con sus otros hermanos - Gaspar y Fernando-, una fecunda actividad entre 1550 y 1579 , básicamente pintando guadameciles para la capilla mayor de muchas iglesias de lugares con escasos recursos económicos - con ello solucionaban el problema temporalmente hasta de poder financiar la construcción de un retablo definitivo ${ }^{9}$ -

Así pues, hacia 1575, Pedro, con veinte años, entraría en su taller y no sólo acabaría de formarse sino que también, como es muy normal en estos casos al convivir en casa del maestro durante varios años, acabaría casándose con su hija, Melchora Marín, pasando a ser su discípulo, compañero de trabajo, amigo y yerno.

\footnotetext{
${ }^{7}$ Archivo Histórico Provincial de Jaén (A.H.P.J.). Legajo 4782, fols. 247-247v.

${ }^{8}$ Ibidem, fols. $157-157 \mathrm{v}$.

${ }^{9}$ En la sublevación de las Alpujarras muchos templos se vieron muy afectados en su patrimonio artístico. Por lo que, una vez sofocada la revuelta, hubo que volver a amueblarlos, si bien, ante la magnitud del problema y la limitada escasez de medios, se optó por estas soluciones más económicas hasta poder datarlos de un definitivo retablo mayor.
} 


\subsection{Su primera etapa granadina. Del anonimato a la consolidación. 1575-1590}

Su suegro fallecería para mediados de 1579 - lo tenemos documentado el 5 de mayo vendiendo un carmen de su propiedad en la Carrera del Darro ${ }^{10}$ _, encomendándole su viuda, Isabel Lendínez, todas las obligaciones que había dejado pendientes.

Fundamentalmente, se trataba de la realización de varios doseles de guadamecí para distintas iglesias de la diócesis, destacando el que realizaría para Guadahortuna. Firma como Pedro de Rojas, es decir del mismo modo que su tío Pablo e igualmente figura como él avecindado en la parroquia de Santiago - lo que nos lleva a pensar que Pedro vendría a Granada de la mano de su tío-.

Con el mismo apellido ${ }^{11}$, al año siguiente (1580), concurre a la subasta pública ó almoneda que se hizo en la Plaza de Bibrrambla de las herramientas del taller del difunto Juan de Orea $^{12}$ - lo que, igualmente, nos prueba que estaba dotando al suyo de todos los útiles nocesarios-.

Ciertamente, estos primeros momentos tuvieron que ser duros: así sabemos por el testamento de su padre - Melchor Raxis-, otorgado en 1596, y por el suyo propio, dado en 1626, que al casar no llevó dote alguna, no así su mujer, quien aportó, en 1579, entre enseres para el hogar y dinero en efectivo, un total de 400 ducados. Aunque a punto estuvieron de perderlos ya que la Justicia, a petición de Sabina de Perales, viuda del batidor de oro Juan de Rojas, se los incautó a fin de sufragar con ellos una deuda de 76 ducados que, por ciertas cantidades de oro, su suegro, Juan de Orihuela, le había dejado sin pagar. Por lo que nuestro artista, para evitarlo se comprometió, el 24 de enero de 1581, con la citada Sabina de Peralta a abonarle tal cantidad en el plazo de dos años ${ }^{13}$, aunque la total liquidación de la deuda no tuvo lugar hasta el 12 de mayo de 1584.

Por estos años era vecino de la parroquia de San Gil, donde contraería matrimonio y bautizó a sus tres primeros hijos: Juan (1581), Mateo (1584) y Felipe (1586) —este último uno de los que seguirían el noble oficio paterno-.

Hacia 1587 se avecindó, nuevamente, en la de Santiago, donde nacerían y recibirían las aguas bautismales otros diez hijos más, a saber: José (1588), Andrea (1590), Bartolomé (1592), un segundo Juan (1594), Mariana (1596), Isabel (1598), Pedro (1599), Francisca (1601), Cecilia (1603) y Felipa (1605), teniendo casi todos ellos por «compadre» — padrino- a su tío Pablo de Rojas, excepto de Francisca, que lo fue su tío-abuelo alcalaíno Pedro Raxis —hermano de su abuelo paterno - y de la última, Felipa, que tuvo a Ambrosio de Vico, a la sazón maestro mayor de las obras de la Catedral de Granada, con quien Pedro Raxis colaboró, como después se verá, en numerosas ocasiones ${ }^{14}$.

Para 1608, y así nos lo confirma en su testamento, ya había muerto Melchora Marín, su mujer, pues en el mes de mayo se incoa el expediente matrimonial para sus segundas nupcias con Rafaela de los Reyes ${ }^{15}$, también viuda. La fecha del fallecimiento de Melchora tuvo que ser hacía 1606, pues casi todos los testigos que figuran en dicho expediente matrimonial por parte de Pedro Raxis afirman que hacía dos años que había muerto su primera mujer, recibien-

\footnotetext{
${ }^{10}$ Archivo Notarial de Granada (A.N.Gr.). Legajo 218, fols. 133v.-136v.

${ }^{11}$ Aunque en los primeros años firma como Pedro Roxas y después como Pedro Raxis. A veces lo hace también como Ragis, Rajis, Rages o Raxes.

${ }_{12}$ Martínez Ruiz, Juan. «El taller de Juan de Orea». Cuadernos de la Alhambra (Granada), 1 (1965), pp. 59-74.

13 A.N.Gr. Legajo 232, fols. 48-48v.

${ }^{14}$ Para no aburrir al lector no damos ni el folio, ni el libro de bautismos donde están sentadas las partidas de todos sus hijos. Solamente señalaremos en su momento las de aquellos hijos que siguieron el oficio paterno: Felipe, Bartolomé y Pedro.

${ }^{15}$ Archivo Histórico del Arzobispado de Granada (A.H.A.Gr.). Legajo 45, pieza 34.
}

$A E A$, LXXVI, 2003, 304, pp. 389 a 406 
do sepultura en Santiago. Incluso entre estos dos años - 1606 y 1608 - ya habían fallecido solteros algunos de sus hijos - el segundo Juan, Andrea y Felipa- De los restantes, José se hizo religioso jerónimo; Francisca y Cecilia quedaron solteras; Mariana casó, en 1618, con Lucas de Valdivieso, tejedor de telas, e Isabel lo hizo, en 1623, con el pintor vecino de Jaén, Francisco de Ariza. Los tres restantes, que continuaron la tradición familiar del cultivo de las artes plásticas, merecen unas breves pinceladas, ya que los tenemos bien documentados.

Así, muy brevemente, y de mayor a menor:

- Felipe: Bautizado en San Gil, el 27 de diciembre, de $15866^{16}$, trabajó tanto en Granada como en Málaga. Para esta última, el 22 de agosto de 1613, contrató el retablo de la Virgen de Loreto del Convento de la Victoria. La pieza, que tendría cuatro varas por media de largo y tres y media de ancho, la realizaría en el plazo de un año y cuya cantidad ascendería a 200 ducados; si bien, dos años después, el 19 de agosto de 1615 - lo que nos indica que no cumplió el plazo estipulado-, traspasó el encargo a Pedro Fernández del Villar ${ }^{17}$.

- Bartolomé: Activo tanto en Sevilla como en Granada, se bautizó, el 25 de agosto de 1592 , en Santiago ${ }^{18}$. Fue el que estuvo más unido al padre, haciéndose cargo de las obligaciones que dejó al morir. Casó dos veces: en primeras nupcias, el 27 de marzo de 1622, con Ana de Jódar ${ }^{19}$, sobresaliendo de entre sus hijos Pedro ${ }^{20}$ y Francisco ${ }^{21}$, por seguir la tradición familiar del cultivo de las artes. Y de segundas lo hizo, en 1642, con María de Oblare, falleciendo el 9 de octubre de $1647^{22}$.

- Pedro: Bautizado en la misma parroquia, el 21 de diciembre de $1599^{23}$, murió el 30 de marzo de 1640, destacando de entre sus muchos trabajos documentados la decoración, en 1628, de la primera escalera del Hospital del «Beato» Juan de Dios y juntamente con su hermano Bartolomé colaboró en la decoración de los armarios-relicarios de la Capilla Real, hechos por Alonso de Mena.

Finalmente, de su segundo matrimonio, con la dicha Rafaela de los Reyes sólo sobrevivió su hija Baltasara quien, nacida en 1612, siendo vecino ya de la parroquia de las Angustias, casaría en 1629 con el pintor y dorador granadino, muy vinculado posteriormente a Alonso Cano, Juan Vélez de Ulloa ${ }^{24}$ - pensamos que, al igual que su otro yerno Francisco de Ariza, aprendió el oficio en su taller-.

Hemos querido detenernos en su situación familiar, porque esta larga descendencia donde abundaba el elemento femenino que, por imperativo de la época, habría que dotar bien para el

\footnotetext{
${ }^{16}$ Archivo de la antigua Parroquia de San Gil — hoy de San Gil y Santa Ana- (A.S.G.A.). Libro de Bautismos de San Gil. Libro 3, f. 98v.

${ }^{17}$ Llorden, Andrés. Pintores y doradores malagueños: Ensayo histórico documental (Siglos XV-XIX). Ávila: Real Monasterio de San Lorenzo de El Escorial, 1959 pp. 158 y 186-189.

${ }^{18}$ Archivo de la desaparecida parroquia de Santiago, hoy en la de San Andrés (A.S.A.). Libro de Bautismos. Libro 3, 4 y 5 , f. 109.

${ }^{19}$ Su expediente matrimonial es muy original, pues por él sabemos que, casi al mismo tiempo, ella —de 18 años de edad - estaba comprometida y se estaba amonestando para matrimonio con un tal Diego de Vega, de 22 años. Ante esto Bartolomé Raxis, que declara tener 28 años de edad, acude al Provisor del Arzobispado, D. Bernardo de Alderete, quien manda realizar una información al respecto. Aquí, la susodicha Ana de Jódar declara que quiere casarse con Bartolomé, con quien está comprometida desde hace ya algún tiempo, corroborando esta afirmación Alonso Caldo y José Antonio de Lopera, doradores, y Juan Bautista Castellano, pintor. (A.H.A.Gr. Vicaría. Año 1622).

${ }^{20}$ Este Pedro, llamado así, probablemente en honor a su abuelo, destacaría especialmente como dorador, tanto en Granada - tenemos documentos algunos para la Catedral- como en Málaga. Así en 1653, avecindado en ella se comprometía a dorar el retablo de San Bernardo, en el plazo de 10 meses y por 1.200 ducados. Para más datos, véase Llorden, Andrés. Pintores y doradores..., p. 236.

${ }^{21}$ Se formó en el taller de Ambrosio Martínez de Bustos. A.N.Gr. Legajo 729, fols. 489-490.

${ }^{22}$ Era feligrés de la Iglesia Parroquial de las Angustias, donde recibió sepultura al día siguiente. Archivo Parroquia Angustias (A.P.A.). Libro de Entierros. Libro 4, f. 126.

${ }^{23}$ A.S.A. Libro de Bautismos. Libro 3, 4 y 5, s/f.

${ }^{24}$ A.N.Gr. Legajo 598, fols. 530-533.
} 

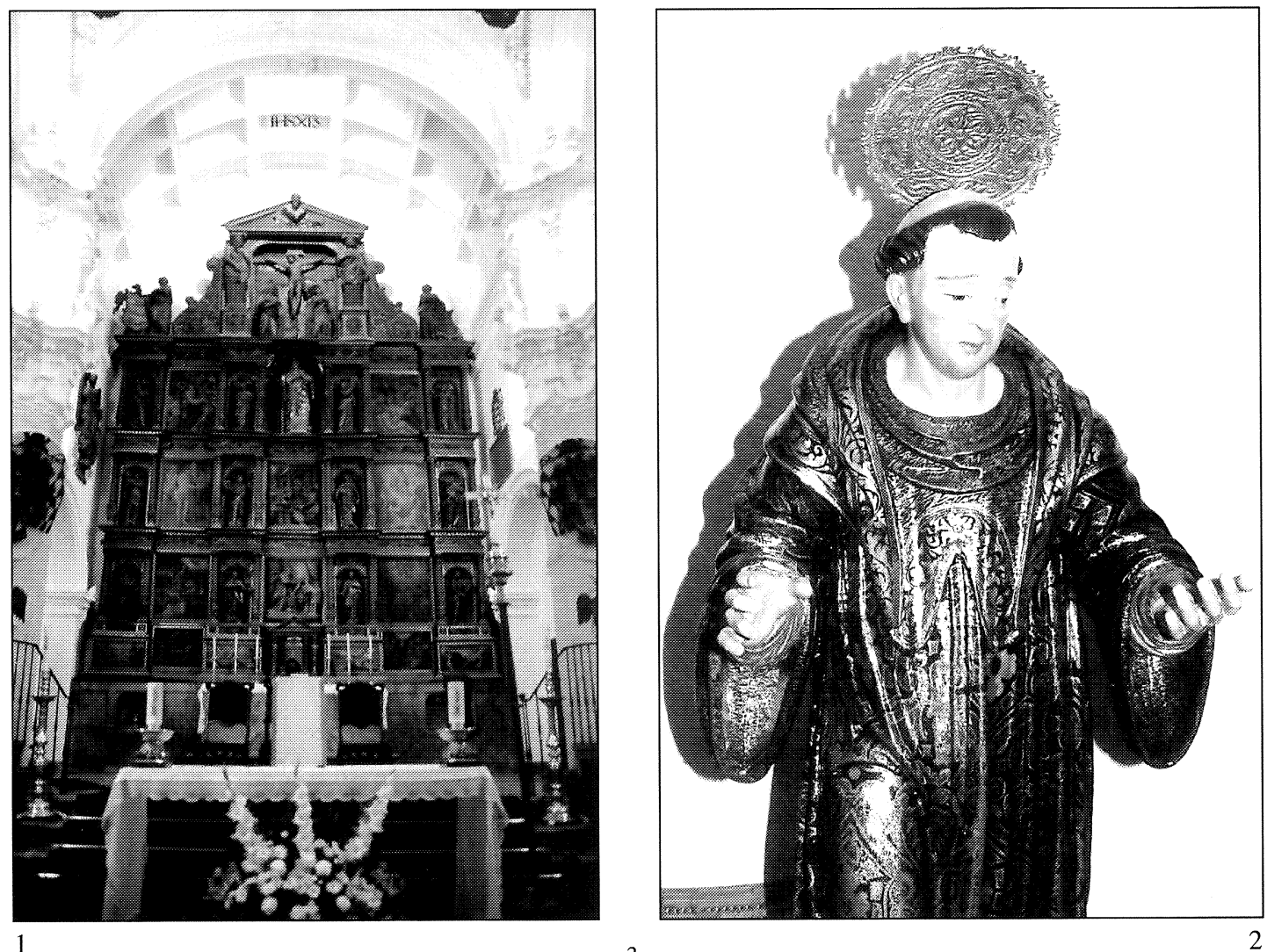

1

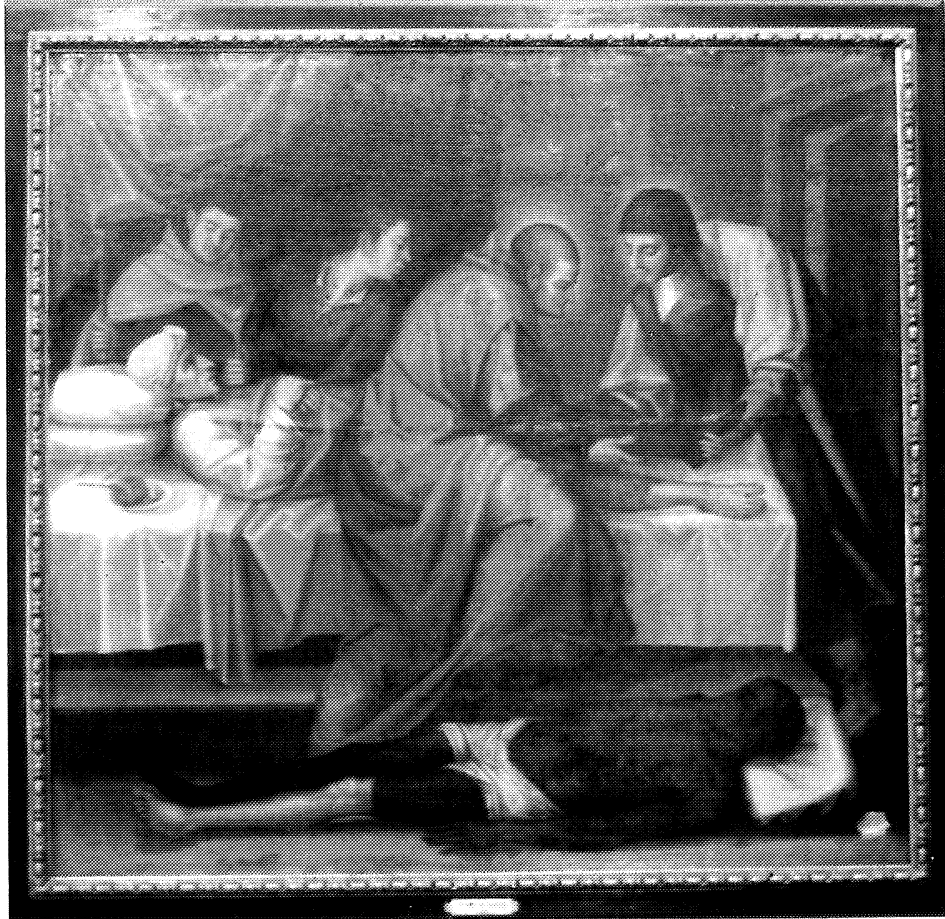

Fig. 1. Priego de Córdoba, Parroquia de la Asunción. Retablo mayor, 1582.

Fig. 2. San Gil. Iglesia de San Gil y Santa Ana, Granada.

Fig. 3. Milagro de San Cosme y San Damián, 1592. Museo de Bellas Artes, Granada.

AEA, LXXVI, 2003, 304, pp. 389 a 406 
casamiento, sería, en nuestra opinión, uno de los varios condicionantes que obligaron a nuestro artista a acaparar cuantas obras se le ofreciesen o saliesen a subasta. Así, cuántas veces nos encontramos a Pedro Raxis pidiendo un anticipo a los comitentes o compañeros de trabajo para poder dotar a tal o cual hijo/a.

Simultáneamente, tampoco olvidemos la injusta situación social en que se desenvolvía la actividad laboral de los artistas en este momento donde, salvo casos muy excepcionales, los patronos o comitentes imponían en los contratos cláusulas realmente abusivas. Dos ejemplos, a este respecto, pensamos que son altamente ilustrativos: el primero acaece en la temprana fecha de 1582, el día 28 de septiembre, Pedro Raxis contrata, junto con el pintor Ginés López, el policromado y las pinturas del retablo mayor de la Asunción de Priego de Córdoba, por 1.800 ducados ${ }^{25}$. Una vez acabado el trabajo, como era lo normal, sería tasado por maestros de reconocido prestigio, si lo fijado fuera inferior a la dicha cantidad, ellos devolverían a la fábrica parroquial la demasía, pero si fuese al revés, ésta no estaba obligada a pagarles nada. Mucho más duro es el segundo ejemplo, por el cual se obligaba, el 9 de enero de 1616, junto con Bernabé de Gaviria, a realizar por 4.750 ducados y para D. ${ }^{a}$ Francisca Fernández de Córdoba, el retablo mayor del Convento, Casa Grande, de San Francisco de Granada. Igualmente tras la tasación final, ella no sólo no les daría nada si el precio final fijado fuese superior a la dicha cantidad, sino que, además de obligarlos a adaptar al retablo ciertas pinturas y tallas preexistentes, debidamente restauradas, se reservaba 500 ducados durante algunos años para subsanar todas aquellas imperfecciones que pudieran surgir a posteriori ${ }^{26}$. Si en el primer caso citado nuestro artista estaba en sus comienzos profesionales, por lo que tendría que transigir en algunos aspectos, todo lo contrario sucede con el segundo, pues, sin lugar a dudas, para esas fechas -1616-, tanto Pedro Raxis como Bernabé de Gaviria eran las figuras más prestigiosas y solicitadas de su entorno socio-laboral. Es decir, ambos ejemplos son altamente ilustrativos de la situación y consideración de estos hombres en la sociedad del Antiguo Régimen, donde eran valorados más como buenos artesanos que como verdaderos artistas, en el sentido estricto del término, lo que repercutiría evidentemente en el importe de los encargos.

Tampoco podemos ignorar al trazar su perfil profesional algo que creemos básico y fundamental: Pedro Raxis fue no sólo un artista muy complejo: pintor — cultivando casi todos los géneros y técnicas-, dorador, estofador, etc. sino que, juntamente, era dueño de un polifacético taller, es decir, un activo y diligente empresario que se movía con criterios estrictamente mercantilistas. De ahí que tengamos que distinguir muy bien entre su obra personal, donde hay un claro afán de superación al compás de las corrientes estilísticas del momento - pensemos en el singular cuadro de la Aparición de la Virgen a San Jacinto, del Museo de Bellas Artes de Granada, o la soberbia Asunción del retablo mayor de la Zubia, ambas obras suyas personales- de lo producido o realizado por su taller, en líneas generales de menor calidad — sirvan como ejemplo las pinturas del retablo mayor de Albolote-.

Es decir, Pedro Raxis, aparte de los dos primeros condicionantes señalados y quizás influido por ellas - larga descendencia familiar y las duras condiciones sociales del momentomontó un complejo y amplio taller que había que tener a pleno rendimiento para que fuera rentable. A ello colaboró el momento histórico, sumamente favorable, ya que tras las directrices cultuales emanadas de Trento, y particularmente en Granada tras el aplastamiento de la sublevación morisca, surge por parte de los representantes de la Iglesia, de las órdenes religiosas, de las cofradías y hermandades e, incluso, de la nobleza para sus fundaciones piadosas, el deseo de dotar a sus espacios religiosos de los bienes muebles necesarios. De ahí que se ocu-

${ }^{25}$ Peláez del Rosal, M. «El retablo del altar mayor de la Parroquia de la Asunción». Adarve (Priego de Córdoba), 1976, pp. $1-4$.

${ }^{26}$ A.N.Gr. Legajo 487, fols. 264-270v.

AEA, LXXVI, 2003, 304, pp. 389 a 406 
para, amén de trabajos de amplia envergadura — policromado de retablos, decoración mural de conjuntos arquitectónicos, como bóvedas de distintas iglesias-, etc., en otras muchas ocasiones, son ínfimos encargos para un artista de su talla; sin embargo, totalmente necesarios para sacarle a su obrador el máximo rendimiento económico posible.

En esta última línea, estos dos ejemplos, que exponemos, son muy ilustrativos: en 1586 se comprometía a policromar, por 110 reales, la caja del órgano y la tribuna del coro de la antigua iglesia granadina de la Magdalena ${ }^{27}$ y algunos años más tarde, en 1616, estando en su plenitud profesional, contrataba, por 44 ducados, una imagen de San Blas para la Taha de Marchena ${ }^{28}$. Ciertamente, él no era escultor, a lo más la policromaría, encomendando previamente su hechura a algún colaborador de su taller o de fuera.

Este último caso nos lleva a constatar otros dos hechos que están muy presentes en su trayectoria profesional. Unas veces es la subcontrata de obras a un segundo artista, en otras la búsqueda de otro maestro que complementara la labor a realizar. Dentro del primer supuesto, tenemos el policromado y las pinturas del citado retablo de Albolote. Efectivamente, ambas labores se había comprometido a realizarlas, sin embargo después, como se verá, le encomienda la primera tarea a otro maestro, quedándose él y su taller con la realización de las pinturas ${ }^{29}$. En el segundo supuesto, y es un buen ejemplo del espíritu de colaboración que estuvo siempre presente en su vida profesional, nos lo encontramos, cuando la envergadura del trabajo o la prisa en acabarlo lo requería, nuestro artista buscaba la ayuda o de compañeros, como la de los pintores Ginés López, Blas de Ledesma, Diego Domedel para decorar la monumental escalera del Convento de Santa Cruz la Real; la de sus hijos, en especial la de Bartolomé o la de escultores y arquitectos como Bernabé Gaviria, —-formado con su tío, Pablo de Rojas era, asimismo, sobrino de su mujer, D. ${ }^{a}$ Ana de Aguilar- para el retablo mayor del Convento, Casa Grande, de San Francisco de Granada; la de Gaspar Guerrero para el de Santa Ana de la Catedral y, muy especialmente, en los últimos años de su vida la de Alonso de Mena, con quien mantendría no sólo estrechos vínculos laborales, sino también personales. Mas de todas las posibles colaboraciones, sin duda, la más continuada a lo largo del tiempo y hasta su muerte, en 1611, fue con su tío Pablo de Rojas - ya señalamos que fue el padrino de bautismo de casi todos sus hijos-, justo en la faceta en que más ha sido ponderado por la historiografía a lo largo de los tiempos, es decir, el estofado y encarnado de imágenes. Algo que, en esencia, venía a enriquecer y completar los valores plásticos de la gubia del genial artista alcalaíno. Así, hoy, podemos confirmar que el 4 de octubre de 1594, Pedro cobraba 200 reales por encarnar y dorar - el perizoma - del excepcional crucificado que su tío había hecho para sacristía de la catedral $^{30}$ - se exhibe actualmente en la antigua sacristía de beneficiados- Y en 1611, año del fallecimiento de Pablo, sin testar y sin hijos, su viuda, D. ${ }^{a}$ Ana de Aguilar, le daba, aparte de 56 ducados que le habían correspondido como a todos los sobrinos de la herencia, $144 \mathrm{du}-$ cados que aún le adeudaba por ciertos trabajos realizados ${ }^{31}$.

Por último, no podemos dejar de comentar como su taller, que hasta comienzos del Seiscientos estuvo situado en las collaciones de San Gil y Santiago, sucesivamente, y a partir de aquí en la de las Angustias, fue una magnífica escuela de arte donde se formaron, además de sus hijos ya mencionados - Felipe, Bartolomé y Pedro-, otros muchos jóvenes que andando el tiempo pasaron a ser sus oficiales o crearon su propio obrador. En el primero de los casos

\footnotetext{
${ }^{27}$ A.H.A.Gr. Contaduría de los hábices de la Magdalena.

${ }^{28}$ A.N.Gr. Legajo 489, 2 abril 1616, s/f debido a la humedad.

${ }^{29}$ A.N.Gr. Legajo 412 , fols. $1513 \mathrm{v}-1514 \mathrm{v}$

${ }^{30}$ Archivo de la Catedral de Granada (A.C.G.). Legajo 163, 4 octubre 1594, s/f. Dato facilitado por D. Juan Ruiz.

${ }^{31}$ A.N.Gr. Legajo 447. fols. 1499-1504. Si bien por el testamento del dicho Pedro Raxis sabemos que estos 144 ducados no se los pagó en efectivo sino dándole una viña, de 14 marjales, en el pago de Cújar.
}

$A E A$, LXXVI, 2003, 304, pp. 389 a 406 

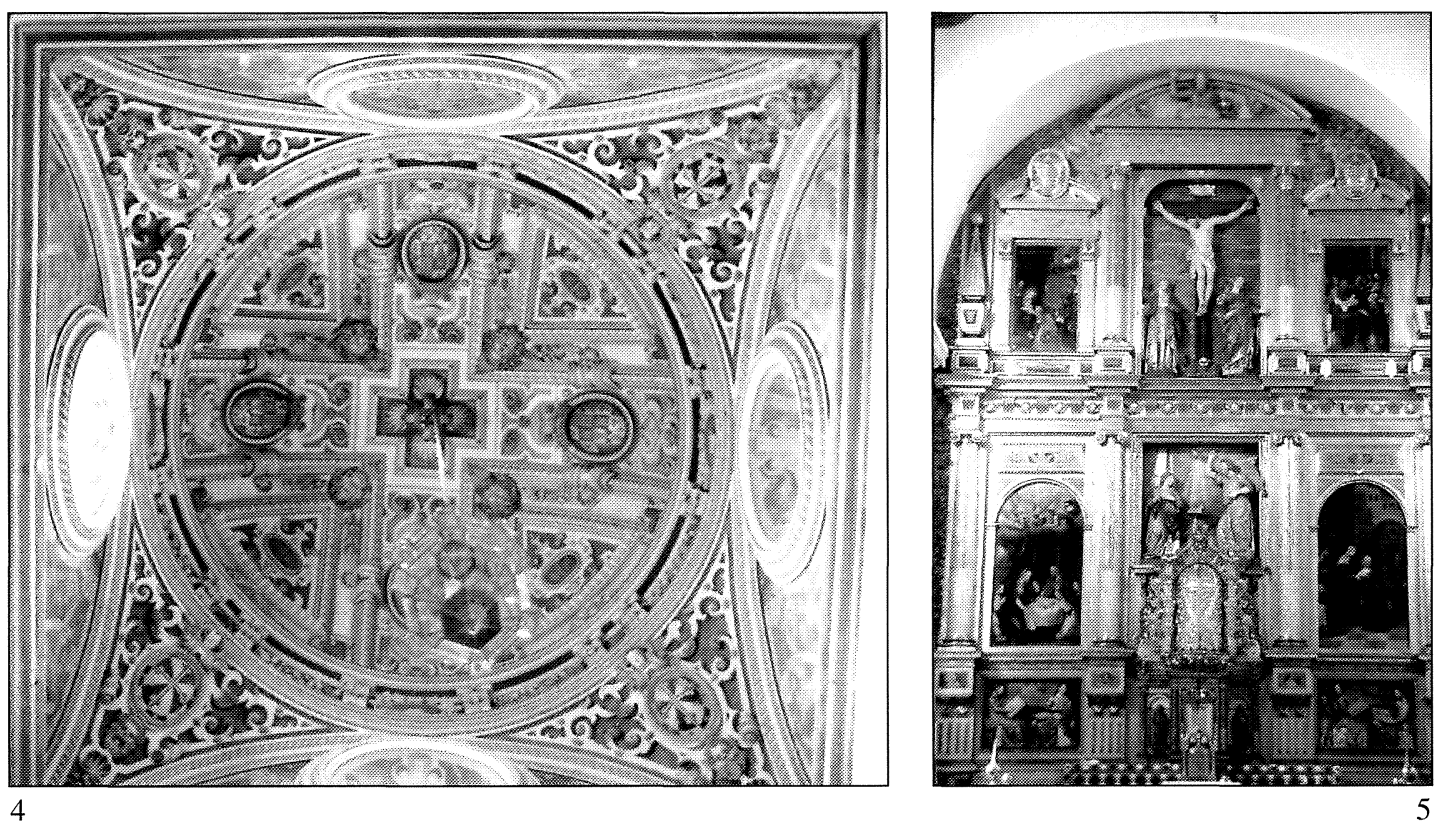

4

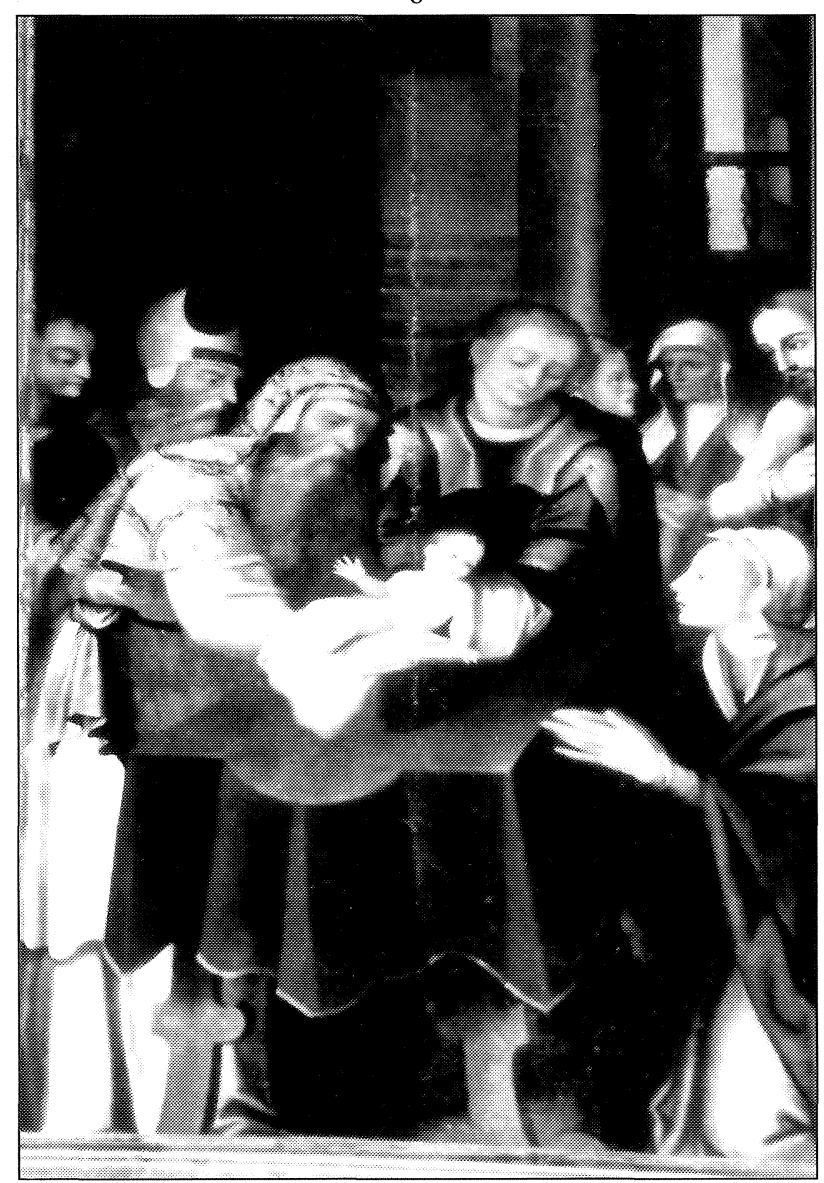

Fig. 4. Convento de Santa Cruz la Real. Escalera principal, 1597.

Fig. 5. Albolote (Granada). Retablo mayor, 1605-1607.

Fig. 6. Albolote (Granada). Retablo mayor, La Presentación de Jesús, 1607.

$A E A$, LXXVI, 2003, 304, pp. 389 a 406 
tenemos a Francisco Velásquez y a Alonso Caldo, a quienes en su última voluntad recuerda deberles ciertas cantidades por sus salarios. Mientras en el segundo nos encontramos con Salvador de Trigo, a quien, en 1618 y con 11 años edad, recibía como aprendiz ${ }^{32}$ y muy especialmente a Guillermo Lamberto, un joven inglés, quien tras declarar, en 1616, que no tiene padres, ni tutor y ser mayor de veinticinco años, entraba a trabajar con él por dos años, quedando el maestro obligado a darle, aparte de lo normal en estos casos - comida, cama, ropa limpia-, dos ducados mensuales y sobre todo enseñarle el arte de «pintar y estofar ymagenes» ${ }^{33}$. Entre ambos nacería una buena amistad, pues, posteriormente, en algunas ocasiones el pintor inglés, que abrió taller en la Parroquia de la Magdalena, salió como fiador o testigo de su antiguo maestro y amigo.

Si hasta aquí hemos intentado analizar una serie de ideas generales, básicas para comprender la trayectoria de nuestro artista, aunque en algunos momentos somos conscientes de que podemos fatigar al lector por el abundante número de datos aportados; a partir ahora, vamos a exponer aquellos encargos de más envergadura materializados durante este primer periodo.

Uno de sus primeros trabajos de gran amplitud, aparte de los ya mencionados doseles de guadamecí que, en nombre de su fallecido suegro, hizo para distintas iglesias de la diócesis, fue terminar, en 1582, juntamente con el pintor y dorador Ginés López, el retablo mayor de la iglesia de la Asunción de Priego de Córdoba.

Con esto se completaba uno de los más hermosos retablos que de la antigua jurisdicción abacial alcalaína, por fortuna, nos ha llegado a la actualidad, cuya arquitectura e imaginaria ya llevaba algún tiempo hecha, sin lugar a dudas en el vecino taller alcalaíno de su familia, con la colaboración de Jusepe de Burgos y muy probablemente también con la de Diego de Pesquera. Pues no olvidemos que el sochantre de esta iglesia era el clérigo Gaspar Ragis, el primogénito de Pedro Raxis, el Viejo y, por lo tanto, tío carnal de nuestro pintor.

Este encargo, del que ya hemos anticipado algunos pormenores y que, en resumen, consistiría, en dorar y policromar su imaginería y su arquitectura y en pintar unos cuadros para completar su iconografía, presupone que Pedro Raxis, aparte de las presiones que pudiera ejercer su tio Gaspar a la fábrica de esta parroquia para que se le encomendase tal misión, valorada en 1.800 ducados, tendría que ser, ya para estas fechas, un hombre de reconocida fama y con algunas realizaciones de prestigio.

Una de ellas hubo de ser la que hizo en el retablo de la primera capilla del Hospital de San Juan de Dios de Granada. El mismo Pedro nos da la noticia el día 2 de agosto de 1583, cuando estando en Alcalá la Real, a donde había venido haciendo un descanso en su trabajo del citado retablo de Priego, le daba plenos poderes a D. Luis Páez de Acuña, contador mayor del Arzobispado de Granada, para que pudiese cobrar del administrador del susodicho hospital, del prior y frailes del convento de San Jerónimo los maravedís que aún le adeudaba de «...dorar, pintar $y$ estofar...» un retablo ${ }^{34}$ que se había hecho para este centro hospitalario ${ }^{35}$.

Compuesto el retablo prieguense de tres calles y cuatro entrecalles en vertical, así como tres pisos, además del banco y el ático, que remata la calle medial, en horizontal. Las pinturas, como es lo normal, se exponen en las calles laterales, comenzando por el banco (Fig. 1). Están dedicadas a la Pasión de Cristo con este orden: la Última Cena, la Oración en el Huerto, los Azotes, Cristo camino del Calvario, la Piedad, la Resurrección, la Ascensión y Pentecostés, resultando difícil deslindar, pues necesitan una profunda limpieza, lo que es de nuestro artista

\footnotetext{
${ }^{32}$ A.N.Gr. Legajo 503, fols. $683 v-684$

${ }_{33}$ A.N.Gr. Legajo 502. 28 agosto 1618 , s/f.

${ }^{34}$ En el Museo que la Orden Hospitalaria tiene en la Casa de los Pisas hay un San Sebastián y un San Roque salidos, probablemente, de la mano de Pablo de Rojas que, tal vez, procedan de este primer retablo.

${ }^{35}$ A.H.P.J. Legajo 4676, fols. 92v-93.
}

AEA, LXXVI, 2003, 304, pp. 389 a 406 
o lo de su compañero, Ginés López. Lo que sí es evidente es su clara ascendencia italiana, en especial la gracia rafaelesca, la fuerza y densidad de Miguel Ángel y la dulzura de Sebastiano del Piombo. Es decir, nos encontramos ante un conjunto excepcional de pintura romanista de finales del Quinientos. Mucho más apegado a la tradición granadina se nos muestra, en cambio, en los bellísimos estofados que policroman sus arquitecturas: cabecitas de ángeles, candelieri, guirnaldas de flores y frutos ${ }^{36}$.

De estos momentos iniciales, de clara ascendencia italiana, está el cuadro de la Anunciación -óleo sobre lienzo - que se conserva en la parroquia granadina de San Cecilio. Situado en la capilla que da paso a la sacristía lo descubrimos en 1992 cuando realizábamos el inventario de dicha iglesia. Va firmado en la parte inferior como «Rojas $\mathrm{f}(\mathrm{ecit}) »$, siendo el arcángel por su dibujo y colorido un trabajo de subida calidad ${ }^{37}$.

Otra obra temprana, ahora como policromador y estofador, lo que le dio más fama y trascendencia, es el San Gil, titular de su antigua parroquia - suprimida a mediados del siglo XIXy hoy en el presbiterio de la de Santa Ana (Fig. 2). La imagen, tal vez, de Diego de Aranda y de composición bastante dura es, en cambio, una pieza maestra tanto por el excepcional estofado del hábito del Santo, de ricos motivos florales, como por la carnación de las manos y el rostro, realizada con un primor y un detallismo excepcional ${ }^{38}$.

Más original, extenso y complejo es el trabajo que comentamos a continuación, pues no sólo nos demuestra que su fama pronto rebasó, copiosamente, su estricto ámbito geográfico, sino que además nos lo encontramos cultivando, y lo hará en otras ocasiones, una faceta - la pintura mural-, hasta ahora desconocida. Así, en 1586 se compromete, junto con Gabriel de Rosales, a decorar distintas bóvedas del Hospital de Santiago de Úbeda. Concretamente, las de la iglesia, antesacristía, sacristía y escalera, todas por fortuna conservadas, aunque necesitadas de una urgente restauración, así como las pinturas, dorado y policromado del desaparecido retablo mayor ${ }^{39}$. Evidentemente, se trata de una empresa de gran envergadura, que tuvo como mentor al Cabildo de la Iglesia Colegial de Úbeda - Patrono del dicho hospital por decisión de su fundador, el obispo D. Diego de los Cobos, que encargó la obra al arquitecto Andrés de Vandelvira - y con un programa iconográfico de tipo bíblico, histórico, funerario y de exaltación de la caridad, es decir, una exposición de clara raíz contrarreformista ${ }^{40}$.

En esta misma línea, aunque su cronología está aún sin precisar, están las pinturas de las bóvedas — cuatro en total - de la nave central de la Iglesia Parroquial de Villacarrillo. Nos hallamos de nuevo ante un complejísimo programa iconográfico, netamente trentino, dedicado a exaltar tanto el origen divino de la Iglesia como su decidido papel en la Historia de la Humanidad ${ }^{41}$.

También tenemos documentada su participación, por estas fechas, en las pinturas y dorado del desaparecido retablo mayor de la iglesia de Santa María de Alcaudete ${ }^{42}$. De este modo se

\footnotetext{
${ }^{36}$ Para más información al respecto véase mi obra Arte y artistas..., pp. 188-198.

${ }^{37}$ En la reciente exposición celebrada en la Catedral de Granada con motivo del Jubileo del 2000 estuvo expuesto, si bien en la ficha del catálogo aparece como «Anónimo» para señalar a continuación «firmado Roxas f(ecit)», lo cual, creo es una enorme contradicción. Para más información, Justicia Segovia, Juan José. «Encarnación». En: Jesucristo y el Emperador Cristiano. Ed. Francisco Javier Martínez Medina. Córdoba: Obra Social y Cultural CajaSur, 2000, p. 201. Finalmente, con tal motivo - y es muy de agradecer - se ha restaurado de lo estaba bastante necesitado.

${ }^{38}$ Debo esta noticia al profesor Dr. D. José Manuel Gómez-Moreno Calera.

${ }^{39}$ Agradecemos, muy sinceramente, a nuestro buen amigo y gran investigador de temas ubetenses D. Vicente Miguel Ruiz Fuentes el que nos haya facilitado estas interesantes noticias.

${ }^{40}$ Para más información sobre los distintos programas iconográficos Montes Bardo, Joaquín. El Hospital de Santiago de Ubeda. Arte, mentalidad y culto. Úbeda: Universidad Nacional de Educación a Distancia, 1995, pp. 67-145.

${ }^{41}$ Un estudio más detallado puede verse en Pérez Lozano, Manuel. «Pinturas de Pedro Raxis en la Asunción de Villacarrillo». Apotheca (Córdoba), 5 (1985), pp. 78-97.

42 Una buena descripción de este desaparecido retablo la podemos encontrar en Madoz, Pascual. Diccionario geográfico y estadístico de España y sus posesiones de Ultramar. Madrid: Establecimiento Tipográfico Literario Universal, 18451850, t. I, p. 434.
} 
acababa de dignificar la nueva capilla mayor de este grandioso templo, ámbito que, diseñado por Francisco del Castillo, hacia 1585, venía a sustituir a otra más sencilla, realizada medio siglo antes por el arquitecto vasco, afincado en Alcalá la Real, Martín de Bolívar.

Tales encargos, evidentemente, le obligarían a pasar largas temporadas fuera de Granada, por tal razón es parca su presencia en los protocolos notariales, aunque no debemos olvidar que tales fondos nos han llegado muy mermados a la actualidad. Para 1588 ya estaría de vuelta, siendo ahora cuando contrata el dorado y estofado de uno de los retablos más emblemáticos de la Catedral, nos referimos al primitivo de Nuestra Señora de la Antigua. Sustituido a principios del siglo xviII por el actual, debido al mecenazgo de D. Martín de Ascargorta y al buen hacer de Duque Cornejo. También policromaría las imágenes talladas por Pablo de Rojas - San Cecilio, San Gregorio, San Esteban y San Juan Evangelista-, hoy expuestas en la girola del templo catedralicio, son un magnífico ejemplo de su buen quehacer como estofador, destacando sobremanera el franjón delantero de la dalmática del Protomártir donde nos ofrece, con delicado primor, el momento de su lapidación. Precisamente, en 1590, otorgaba carta de finiquito de lo que aún se le adeudaba por este trabajo.

Los años finales de siglo serán también de una febril actividad. Así, en 1592 pinta el cuadro de los Santos Cosme y Damián (Fig. 3) para el convento de los Mártires, de Carmelitas Descalzos, hoy en el Museo de Bellas Artes, no siendo ésta la única ocasión en que trabajó para este lugar. En 1594 policroma el Crucificado ya mencionado de la Catedral, por el que cobró 200 reales. En 1597, se compromete, junto con Blas de Ledesma y Diego Domedel a decorar la bóveda de la majestuosa escalera del Convento de Santa Cruz la Real (Fig. 4). Levantada por los Vilches, maestros de cantería de origen baezano, y por Francisco Gutiérrez, maestro de albañilería, oriundo de Antequera, en ella despliegan un complejo programa dedicado a exaltar a los Reyes Católicos, fundadores del mismo, a la Orden de los Predicadores y a la Virgen María ${ }^{43}$.

Precisamente, por estos mismos años y para este hermoso lugar pintó el mencionado cuadro de la Aparición de la Virgen a San Jacinto — santo dominico, de origen polaco, canonizado en 1594, que gozó de gran predicamento por ser especial intercesor ante la Virgen María-. De amplio formato y concebido en diagonal, por su atrevido colorido - el blanco del hábito, el verde de la cortina que sujetan unos angelitos, etc.- , así como por el decidido naturalismo del rostro del santo, lo podemos considerar como una obra realmente pionera. Paralelamente iniciaba su colaboración en el policromado del proyecto retablístico granadino más ambicioso del momento, nos referimos al retablo mayor de San Jerónimo. Sobre todo, una vez muerto el pintor Juan de Aragón.

Si estos empeños son más o menos conocidos no podemos omitir otros que, aunque, no nos han llegado a la actualidad, son altamente ilustrativos para conocer en profundidad su trayectoria profesional y la envergadura de su taller. Así, el 25 de agosto de 1588, se comprometía con Francisco Jimeno a pintarle por 50 ducados un cuadro -óleo sobre tabla - con la imagen de Nuestra Señora y un clérigo arrodillado a sus pies. Tal cuadro lo había contratado el citado Francisco Jimeno, también pintor, con D. Pedro Guerrero, tesorero de la catedral ${ }^{44}$ pero, como estaba imposibilitado de un brazo, le traspasaba el encargo a nuestro artista —no tendría el tal Francisco Jimeno muy inútil el brazo ya que, acto seguido, se obligaba a hacerle a Pedro Raxis una yluminaçion en pergamino, es decir, una miniatura con el tema de la inposición de la casulla al Sr. San Ildefonso ${ }^{45}$.

\footnotetext{
${ }^{43}$ Más ampliamente este tema fue tratado por López Guzmán, Rafael y Gila Medina, Lázaro. «La arquitectura en Granada a finales del siglo xvi: la escalera del Convento de Santa Cruz la Real». Cuadernos de Arte de la Universidad de Granada, 23 (1992), pp. 159-188.

${ }^{44}$ A.N.Gr. Legajo 271, fols. 1290-1291v.

${ }^{45}$ Para más información sobre este desconocido monasterio Bermúdez de Pedraza, Francisco. Historia Eclesiástica de Granada. Granada. Edición facsímil de la Universidad-Editorial D. Quijote, 1998, pp. 263-264.
}

AEA, LXXVI, 2003, 304, pp. 389 a 406 
Al citar el cuadro de los Santos Cosme y Damián del convento de los Mártires advertíamos que Pedro Raxis trabajó para él, al menos, en otra ocasión. Ésta tuvo que ser muy a finales de siglo y consistió en pintar, dorar y estofar un sagrario para el mismo y en hacer otro tanto en una imagen de la Virgen para el cercano, y poco conocido, convento del Desierto del Monte Carmelo, todo por 900 reales — 700 el sagrario y 200 la imagen-.

\subsection{La plenitud profesional, 1600-1626}

En los umbrales del Seiscientos, Pedro Raxis estaría en el cenit de su madurez profesional y su taller sería uno de los más solicitados, lo que se acentuaría aún más desde el momento en que se produjera la incorporación al mismo de sus tres hijos que siguieron sus huellas profesionales. Esto le permitirá al padre, entre otras muchas cosas, poder concurrir a numerosas subastas de obras, pujando a la baja y, a veces, en los lugares más insospechados. Tal es el caso del perdido retablo principal de la Iglesia Mayor de Gibraltar, al que Pedro Raxis, en diciembre de 1600, estante en Cádiz, se obligaba, por 2.369 ducados, a dorar, estofar, pintar y hacer dos imágenes - un San Pedro y un San Pablo—, que aún le faltaban para completar su programa iconográfico ${ }^{46}$.

Es también en los albores de la misma centuria cuando, de acuerdo con los condicionantes ya expuestos, se llevan a cabo por parte de las autoridades eclesiásticas —en especial por el arzobispo D. Pedro de Castro y su provisor el historiador Justino Antolinez- la contratación de una serie de retablos para la capilla mayor de algunas iglesias tanto de la misma capital como de algunos pueblos de la diócesis. Diseñados normalmente por el omnipresente Ambrosio de Vico, - padrino de su hija Felipa—, ensamblados por Miguel Cano y teniendo como autores de las tallas a Rojas y Gaviria, etc., en casi todos los casos las pinturas, el dorado y estofado de su arquitectura e imágenes corren a cargo de Pedro de Raxis y su taller.

Así se cumple en el excepcional retablo de la localidad granadina de Acequias, por fortuna el único de la serie que nos ha llegado intacto a la actualidad, si bien necesitado de una urgente restauración. Formado verticalmente por banco y dos cuerpos, su policromado y pinturas — dedicadas a la vida de San Benito, más un calvario completo para el remate de la calle central- son, con toda probabilidad, obra de su taller ${ }^{47}$.

Similar conformación arquitectónica tenían los realizados para las parroquias granadinas de Santa Escolástica, Santa Ana y San Cecilio, hoy todos ellos desaparecidos. Especial interés ofrece este último, pues, por fortuna, las labores que se comprometió a efectuar Pedro Raxis, así como los pagos que fue recibiendo a cuenta de las mismas las tenemos claramente documentadas. Hace ya algunos años el profesor Gómez-Moreno Calera ${ }^{48}$ nos ofrecía algunas noticias tomadas de los fondos del Instituto «Gómez-Moreno», incluso presentaba una reproducción fotográfica de la traza original dada por Ambrosio de Vico y que se guardaba en el archivo de la Capilla Real, aunque se ha perdido recientemente, lo que es muy de lamentar.

Como ya hemos apuntado su diseño, de un elegante acento clasicista, coincide casi en su totalidad con él del retablo de Acequias. Así pues, en esencia tendría por base un doble y bien proporcionado arco de triunfo, compuesto de banco, con el sagrario en el centro flanqueado a cada lado por el escudo arzobispal, y dos cuerpos de tres calles, con columnas jónicas en el

${ }^{46}$ Archivo Histórico Provincial de Cádiz (A.H.P.C.). Legajo 706, fols. 200-214. De nuevo, agradezco a D. Vicente Miguel Ruiz Fuentes el haberme facilitado esta información.

${ }^{47}$ En el presbiterio de la Parroquia de Calicasas - localidad cercana a Granada-, hay un pequeño retablito, cuya policromia y pinturas pueden ser de su taller.

${ }^{48}$ La arquitectura religiosa granadina..., pp. 113 y 161. 
inferior, mientras en el segundo, que funcionaría como un gran ático, eran corintias. También aquí la iconografía seguiría el mismo esquema. Así, en la primera hornacina de la calle medial, iría una escultura de San Cecilio, titular de la iglesia, y en la segunda, en pintura, un calvario completo, mientras los encasamientos de las laterales — dos por cada calle- estarían dedicadas a resaltar la vinculación de San Cecilio con los Apóstoles Pedro y Pablo, así como también a su labor evangelizadora y martirio en estas tierras - precisamente no hacía más de diez años que sus reliquias y de otros de sus compañeros se habían inventado en el cercano Monte de Valparaíso-.

Si el retablo se había mandado hacer el 5 de septiembre de 1602, dos días después Pedro Raxis contrataba con el mencionado provisor y contador mayor del arzobispado, Justino Antolínez, policromarlo y pintar los lienzos necesarios, en un plazo de ocho meses y por 600 ducados, recibiendo 100 a cuenta.

El documento ${ }^{49}$ en cuestión es de un gran interés desde el punto de vista técnico, pues Raxis nos va detallando con total puntualidad las labores que tendría que realizarle. Desde aparejar toda la obra, enlazando y encolando todas las juntas, darle cuatro capas de yeso iniciales, otras de yeso mate, luego el bol, hasta qué tipo de policromía llevarían las cabezas de los serafines de los frisos, los grutescos o los campos de los escudos y el sagrario.

No obstante, nuestro artista ni cumplió con los plazos estipulados ni realizó personalmente todas las labores. Así, por lo que atañe a las pinturas tardó, algo más de dos años, pues si, como vimos, contrató la obra el 7 de septiembre de 1602, recibiendo en ese momento 100 ducados, los últimos se le entregaron el nueve de noviembre de 1604 —entre medias y en cuatro ocasiones distintas fue percibiendo otros pagos con la misma cantidad-. Mientras que por lo que compete a lo segundo, como sucederá posteriormente en Albolote, le traspasará las labores de policromado y dorado a su antiguo socio, en Priego, Ginés López, quedándose él y su taller con las pinturas - lienzos que, desde principios del siglo xvIII en que este retablo se sustituyó por otro nuevo, se exhibieron en interior del templo, para perderse definitivamente en el incendio que lo asoló, en 1969, si bien por fortuna —no lo olvidemos-, hoy guarda una Anunciación de su primera época, que, evidentemente, nada tiene que ver con las pinturas de este retablo-.

Si ya desde la centuria anterior, como anunciamos y especialmente tras el fallecimiento de Juan de Aragón, Raxis venía trabajando en el retablo de San Jerónimo, a partir de 1603, con la ampliación de su arquitectura con otros pisos, su intervención en su policromado se incrementa, concretamente en el banco, en algunos relieves del primer piso, obra de su tío Pablo de Rojas, y en el último cuerpo, destacando especialmente la calidad y originalidad de sus delicadas estofas a base de amplios grutescos de intensos y vivos colores.

La misma compañía laboral nos la encontramos en el ya citado retablo mayor de la vecina localidad de Albolote (Fig. 5). Diseñado hacia 1605 por Ambrosio de Vico, Rojas y Gaviria, entre otros, harían las esculturas mientras que Pedro Raxis se comprometía a policromar la arquitectura y hacer las pinturas necesarias. Sin embargo, dos años después, en 1607, le traspasaba por 409 ducados la primera labor al dorador y estofador Juan Martínez, reservándose para él las pinturas. La obra, ampliamente estudiada por el mencionado Gómez-Moreno ${ }^{50}$, está formada por tres calles y dos pisos, más banco y ático. Las tablas, cuatro en total, recientemente restauradas como todo el conjunto, y situadas en las calles laterales, están dedicadas a los primeros momentos de la vida de Cristo - la Visitación, el Nacimiento, la Epifanía y la Presentación- (Fig. 6). Con un carácter eminentemente narrativo domina la colaboración del taller.

\footnotetext{
${ }^{49}$ Nuestra gratitud a $D^{a}$. Marisa García Valverde y a D ${ }^{a}$. Inmaculada Bertos Maldonado por haberme facilitado tal documento para su estudio. Así como el expediente matrimonial de Bartolomé Raxis.

${ }^{50}$ Ibidem, pp. 280-282.
}

AEA, LXXVI, 2003, 304, pp. 389 a 406 

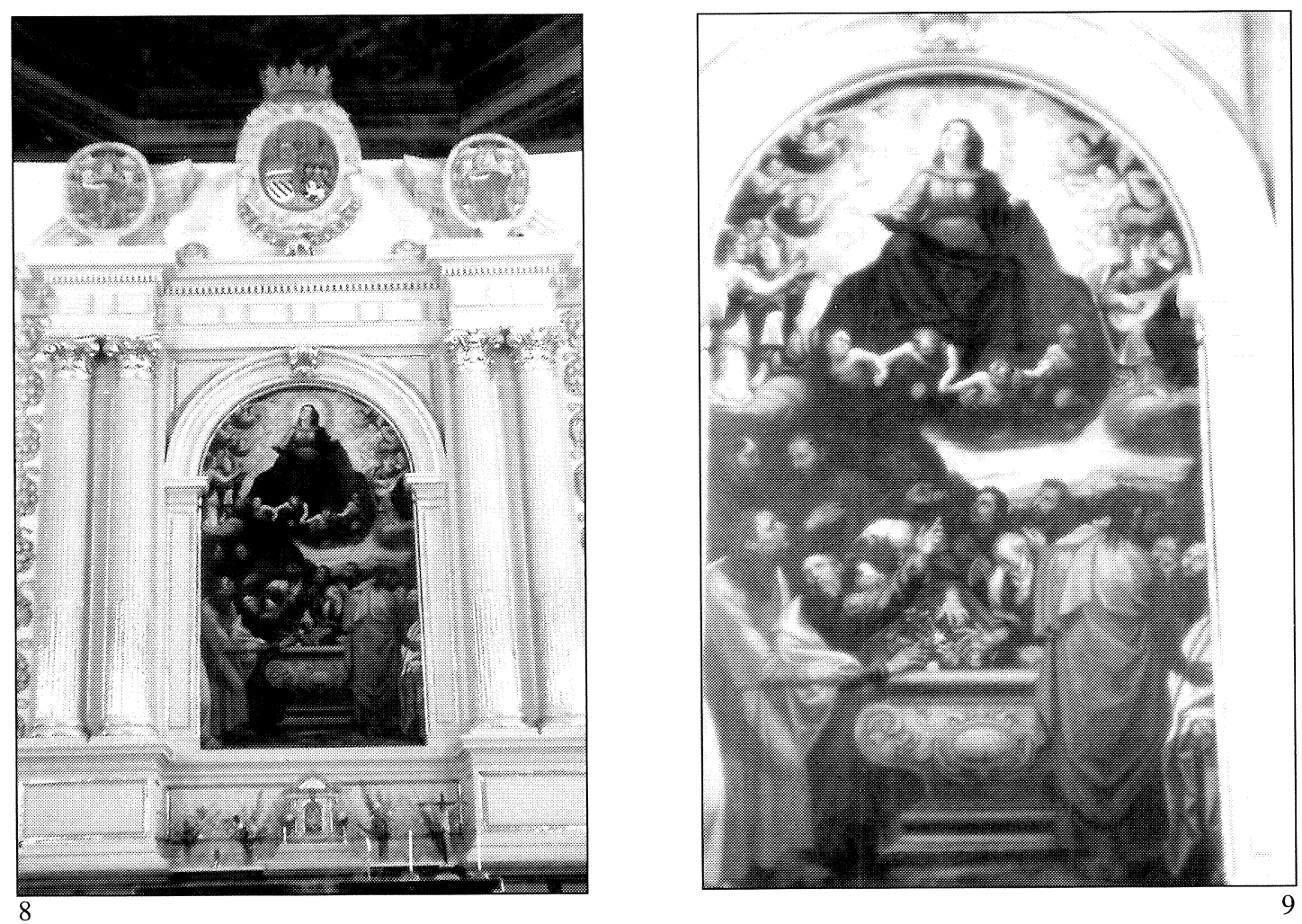

7

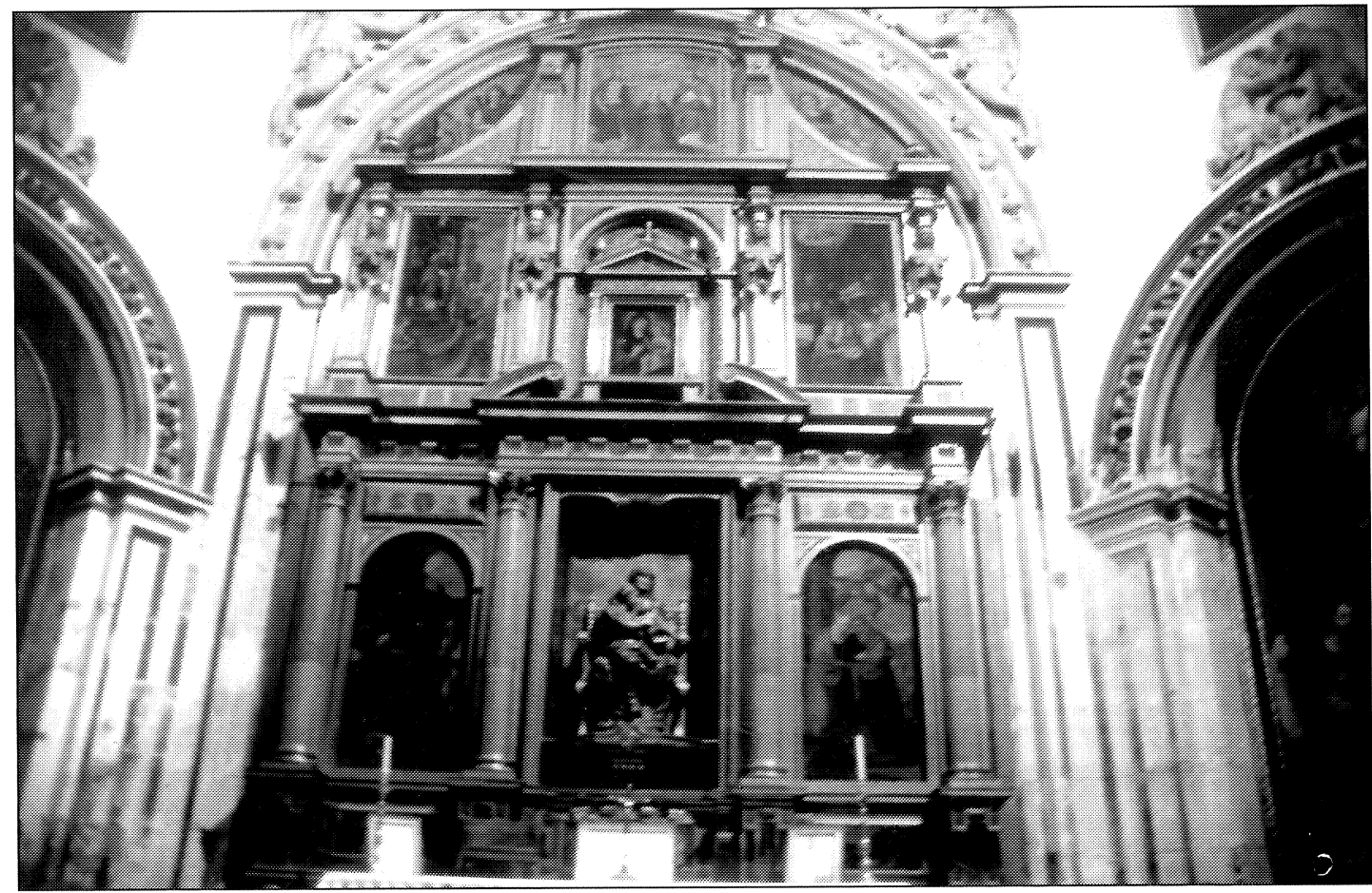

Fig. 7. Granada, Catedral. Retablo de Santa Ana, circa 1616.

Fig. 8. La Zubia (Granada). Retablo mayor, 1615-1616.

Fig. 9. La Zubia (Granada). Retablo mayor, 1615-1616. La Asunción.

AEA, LXXVI, 2003, 304, pp. 389 a 406 
Todo lo contrario que el soberbio cuadro, ya citado, de la Asunción de la Virgen, hecho para el retablo mayor de La Zubia.

Diseñado también por Ambrosio de Vico en piedra, siendo policromado por Raxis aunque su factura actual es más reciente, la delicadeza, elegancia y encanto luminoso de la Virgen (Fig. 8), que ocupa su único y monumental cuerpo y calle, contrasta y se complementa con la fuerza y brío de los apóstoles, que asisten expectantes al acto (Fig. 9). Además, todo ello realizado y realzado con magistrales e intensos toques de luz y color, muy a lo veneciano.

Si esto es de 1615, al año siguiente, se comprometía, junto con Bernabé de Gaviria, a realizar, durante 7 años y por 4.750 ducados el mencionado retablo mayor del Convento, Casa Grande, de San Francisco de Granada. Sin lugar a dudas, dentro de este género es su trabajo de mayor envergadura. Incluso sabemos que, a la hora de otorgar su testamento - 1626 - aún le estaba haciendo ciertas mejoras, ahora juntamente con su hijo Bartolomé. Ya vimos como contratado por D. ${ }^{a}$ Francisca Fernández de Córdoba, viuda de D. Luis Fernández de Córdoba, señor de Órgiva, con ambos artistas, se realizó en los plazos previstos. Si bien a la muerte de D. ${ }^{a}$ Francisca, su nieto y heredero D. Luis Fernández de Córdoba quiso enriquecerlo, valorando nuestro maestro en su testamento estas últimas labores en 400 ducados, aunque sólo tenían recibidos nada más que 1.000 reales — -90 ' 9 ducados-

Aunque no nos ha llegado a la actualidad, el contrato que suscribieron ambas partes es tan minucioso y rico en detalles que nos ha permitido en otra ocasión ofrecer una reconstrucción formal e iconográfica bastante aproximada del mismo ${ }^{51}$. No obstante, aquí, a modo de síntesis, diremos que trazado por Gaviria, constaba, en horizontal, de banco y tres pisos, más ático, y en vertical con tres calles y dos entrecalles. Aquí irían esculturas, mientras en las primeras y en el banco serían pinturas - en algunos casos cuadros preexistentes que Raxis tendría que limpiar y adaptar-.

Paralelamente no podemos dejar de anotar su fama como retratista. Sus retratos, entre los que sobresalen el de San Juan de Dios de la Casa de los Pisas ${ }^{52}$ —en cuyo marco alguien anotó «... Echo por el famoso pin(tor) Raxis», el del beato trinitario Fray Miguel de los Santos, del Museo de Bellas Artes de Granada, o los de varios arzobispos para el episcopologio, aparte de otros consagrados a miembros de la nobleza local, son de un profundo vigor, una gran sobriedad e intensidad expresiva. Precisamente, dentro del segundo grupo, el más logrado es el del arzobispo Fray Pedro González de Mendoza, con quien le unió una estrecha amistad - siendo él quien imponga a los Mercedarios Descalzos que la Virgen de Belén, tallada por Alonso de Mena, hacia 1615, para el Convento del mismo nombre, hoy en la Parroquia de San Cecilio, fuera policromada por él-. No es éste un caso único, pues en numerosas ocasiones al contratarse una imagen el comitente imponía al escultor la condición de que la policromía tendría que ser obra de nuestro artista. Pues como estofador su arte no admite parangón. Muchos casos tenemos documentados más como ejemplo clarividente tenemos que, el 7 de noviembre de 1622, Alonso de Mena contrataba con el mercader Miguel Ruiz una imagen de San Miguel, debiendo ser estofado y grabado de mano de Pedro Rages ${ }^{53}$.

Por estos mismos años trabajó en el retablo de Santa Ana de la Catedral. Trazado por Gas-

\footnotetext{
${ }^{51}$ No obstante, a mediados del siglo XVIII el banco y primer piso de la calle medial sería sustituida por un complejo manifestador. Para más información véase mi artículo: «Nueva aproximación al retablo mayor de la desaparecida iglesia del Convento Casa Grande de San Francisco de Granada». Cuadernos de Arte de la Universidad de Granada, 30 (1999), pp. 81-91.

${ }^{52}$ Aparte de su intervención en el retablo de la primera capilla del hospital y de este retrato del Santo Fundador, en 1622, realizó una primera serie de lienzos, hoy perdidos y sustituidos por otros del siglo siguiente, para el claustro grande de dicho centro asistencial. Cfr. Larios Larios, Juan Miguel. El claustro del Hospital de San Juan de Dios en Granada. Granada: Diputación, 1979, p. 27.

${ }_{53}$ A.N.GR. Legajo 544, fols. 855-856v.
}

AEA, LXXVI, 2003, 304, pp. 389 a 406 
par Guerrero, con un claro predominio de la lógica arquitectónica de raíz clasicista aunque ya se apuntan algunos rasgos barrocos, fue financiado por el gremio de los roperos (Fig. 7). Las tablas de las dos calles laterales -El ofrecimiento anual de San Joaquín y Santa Ana al Templo y el Anuncio del Ángel a San Joaquín, El abrazo en la Puerta Dorada, el Nacimiento de la Virgen y su Presentación-, según ha demostrado Benito Navarrete Prieto, siguen muy de cerca unos grabados de Adrián de Collaert, a través de unas composiciones de Stradanus que figuran en una Vida de la Virgen de finales del siglo XvI ${ }^{54}$. Artísticamente éstas, así como la Coronación de la Virgen y la réplica de la Virgen de los Perdones de la calle medial, son de más calidad que los evangelistas del banco, que los consideramos obras de taller ${ }^{55}$.

Por último, en su testamento declara que tiene en su casa para dorar y estofar dos retablos: uno para el Carmen de Alhama y el otro para el convento de San Jerónimo de Baza. Los dos estaban al cargo de Alonso de Mena quien, a cuenta del primero, le había dado 100 ducados, aunque ya había gastado mucho más. Mientras que para el segundo tenía recibida la misma cantidad y ya estaba casi acabado del todo. Igualmente estaba en deuda con él D. Luis Fernández de Córdoba por las mejoras realizadas al retablo mayor del Convento de San Francisco. Los tres primeros retablos han desaparecido: el primero fue reemplazado, en 1731, por otro comprado a la Hermandad de la Virgen del Rosario de Granada - a su vez perdido en la Guerra Civil—, el segundo tras la exclaustración de Mendizábal, mientras el tercero lo fue con la Invasión Francesa. Si bien, probablemente, algunas de sus esculturas realizadas por Bernabé de Gaviria — San Luis, rey de Francia; Santo Domingo de Guzmán y San Francisco- pueden ser las que junto a las de Pablo de Rojas, procedentes del primitivo retablo de Nuestra Señora de la Antigua, hoy están en la girola de la Catedral de Granada ${ }^{56}$.

\section{Conclusión}

A través de estas líneas hemos intentado ofrecer una aproximación lo más completa posible a la vida y obra Pedro Raxis. Como hemos visto, y no hemos querido ser muy exhaustivos en datos, fue la suya una trayectoria entregada de lleno y con enorme entusiasmo a la producción artística, tanto en el campo de la policromía, en especial de la estofa, de la que fue considerado «el padre» como también — y es algo a tener muy en cuenta posteriormente- en el de la pintura, convirtiendo a Granada en un centro de producción de primer orden. Ojalá pronto podamos gozar de una amplia monografía — una tesis doctoral sería muy de agradecer- donde, partiendo de las pautas aquí señaladas o de otras, se nos ofrezca no solamente una completa biografía y análisis de su obra, sino una ajustada valoración de la significación que nuestro artista, su taller y descendencia tuvieron en su momento cultural ${ }^{57}$.

\footnotetext{
${ }^{54}$ La pintura andaluza del siglo xvIl y sus fuentes grabadas. Madrid: Fundación de Apoyo a la Historia del Arte Hispánico, 1998. p. 35.

${ }^{55}$ Este retablo ha sido estudiado por García García, Juan Alfonso. Iconografía mariana en la Catedral de Granada. Granada: Cabildo Metropolitano, 1988, pp. 130-131. Sin embargo, no coincidimos en todo con su lectura iconográfica.

${ }^{56} \mathrm{Vid}$. nota 51.

${ }^{57}$ De estas líneas nuestro más sincero agradecimiento a D. Antonio Muñoz Osorio, Delegado Episcopal para el Patrimonio Cultural del Arzobispado de Granada y a D. José Galisteo Martínez por su ayuda recibida.
} 


\section{FAMILIA RAXIS SARD0}

PEDRO RAXIS, EL VIEJO

(Cagliari, c. 1506 - Alcalá la Real, 1581)

CATALINA GONZÁLEZ

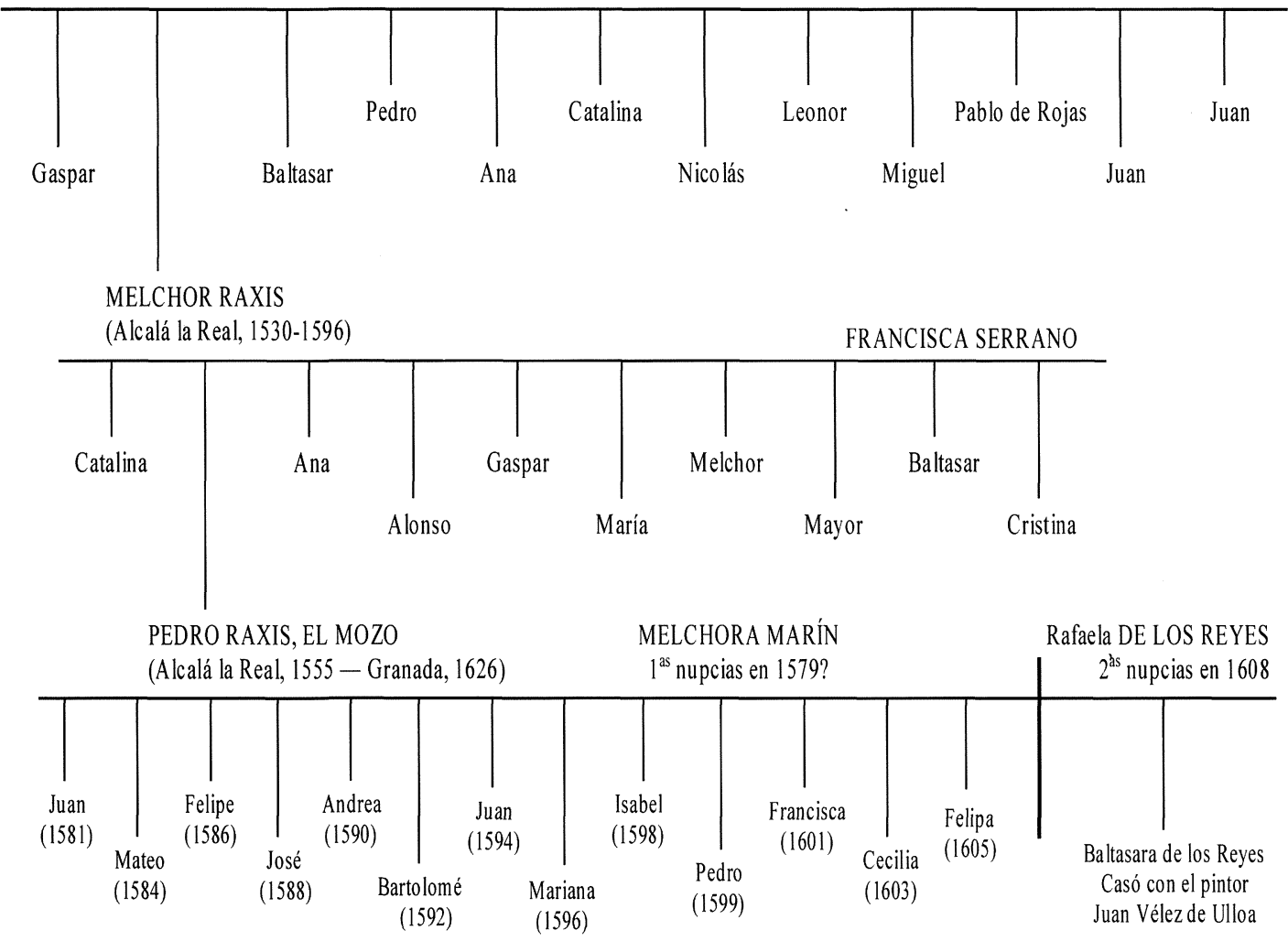

$A E A$, LXXVI, 2003, 304, pp. 389 a 406 